\title{
Physician Discontent
}

\section{A Barometer of Change and Need for Intervention}

$\mathbf{T}$ imes have changed. Historically, physicians have been viewed as allies in improving health. Doctors have functioned with substantial autonomy, and have received significant societal prestige and reimbursement for providing a complex, socially useful job. Societal changes, including the growth of managed care, ${ }^{1}$ increased accountability and requirements for documentation, burgeoning malpractice claims, ${ }^{2}$ growing consumerism,,${ }^{3,4}$ and an erosion of trust, ${ }^{5}$ have changed the practice of medicine, and the relationships between patients and physicians.

At the beginning of the $21^{\text {st }}$ century, many American physicians are discontented with their professional lives. ${ }^{6-10}$ While professional dissatisfaction is clearly not new to physicians, ${ }^{11}$ the causes and solutions have changed. ${ }^{8}$ In this issue of JGIM, Murray et. al. demonstrate a significant decline in the professional satisfaction of primary care physicians in Massachusetts between 1986 and $1997 .{ }^{12}$ To examine this trend, the authors compare two cross-sectional studies that incorporated identical questions about professional satisfaction. The most significant declines in satisfaction were related to the time spent with patients, autonomy in decision-making, and the availability of leisure time.

Studies have identified several facets of physician satisfaction: satisfaction with the quality of care; autonomy; compensation; relationships with patients; relationships with colleagues; and with the practice environment. ${ }^{13-16}$ Work environment may differentially affect different domains of satisfaction. For example, physicians in closedmodel HMOs may have lower satisfaction with resources than physicians in other settings, but they may be more satisfied with regard to autonomy in decision-making and administrative issues. ${ }^{14}$

Why is physician satisfaction important? Physicians may be more effective in their work if they are professionally satisfied. ${ }^{17}$ There is an association between physician satisfaction, the quality of care that they provide, and patient satisfaction. ${ }^{18-20}$ Dissatisfaction may contribute to poorer patient adherence. ${ }^{18}$ Dissatisfaction also leads to job turnover and early retirement. ${ }^{21}$ Both of these generate unnecessary costs associated with decreased continuity of care for patients, and the costs of training new physicians. Low professional satisfaction and high job stress are associated with more health complaints among physicians, and with the filing of disability claims by physicians. ${ }^{22,23}$ Finally, the professional satisfaction of current physicians may influence the future supply of physicians. ${ }^{24}$

An understanding of the characteristics of physicians who are more likely to be dissatisfied may help to design 496 interventions to improve physician satisfaction. Physicians who are younger, ${ }^{13,16}$ female, ${ }^{25}$ receive a lower income, ${ }^{13}$ practice in an urban setting, ${ }^{26}$ work a greater number of hours, ${ }^{27}$ and perceive that the quality of care that they can provide is compromised $^{27}$ are less satisfied than their counterparts. Market and practice characteristics may also influence physician satisfaction. Physicians have had a strong negative reaction to capitation, 8,28 perhaps related to concerns of restricted autonomy and declining reimbursement. ${ }^{27}$

Interventions to improve physician satisfaction can be either local or more far-reaching. Since time constraints are one domain that is a current concern to physicians, one type of local intervention could be directed toward alleviating time pressures. In this issue of JGIM, Waterman et al. present an evaluation of a telephone-based anticoagulation service on the referring physicians' satisfaction with this service. ${ }^{29}$ They report significant time savings associated with using this program, both for the physicians and their staff. This type of service offers many of the advantages and disadvantages of disease management programs. ${ }^{30}$ While they may offer significant time saving, they can also cause a disruption of the patient-doctor relationship. Safeguards, like specific communication protocols, should be incorporated into these types of interventions. While utilization management techniques that curtail physician autonomy are negatively associated with physician satisfaction, the implementation of clinical guidelines is positively associated with satisfaction. ${ }^{31}$ Other local activities could perhaps include programs to promote physician's self-awareness and expectations, since this may improve both professional satisfaction and the quality of clinical care. ${ }^{32}$ While a variety of local programs are necessary to address the specific concerns of physicians in a particular system of care, broader attention to physician satisfaction is also necessary.

Times have changed and health care will continue to evolve. Physician discontent results from a mismatch of expectation and reality. While interventions are certainly necessary to improve the "realities" of practice in turbulent times, medical education should provide physicians with the skills needed to define and re-define their expectations. ${ }^{33}$ Clearer expectations might enable better delineation of the causes of discontent, and allow for better definition of interventions to improve professional satisfaction and the quality of care.

Physician discontent is an important barometer in our evolving health care environment. While discontent may, in part, reflect discomfort with change and unmet 
expectations, it also indicates areas for improvement and intervention. - JeNNifer S. HAAS, MD, MSPH, Division of General Internal Medicine, San Francisco General Hospital, Department of Medicine and The Institute for Health Policy Studies, University of California, San Francisco, Calif.

\section{REFERENCES}

1. Dudley RA, Luft HS. Managed care in transition. N Engl J Med. 2001;344:1087-92.

2. Mohr JC. American medical malpractice litigation in historical perspective. JAMA. 2000;283:1731-7.

3. Runy LA. Consumers in control. How the Net will reshape health care. Hosp Health Netw. 2000;74(suppl):4-7.

4. Lewis FR Jr. Costs, competence, and consumerism: challenges to medicine in the new millennium. J Trauma. 2001;50:185-93.

5. Mechanic D. Changing medical organizations and the erosion of trust. Milbank Quarterly. 1996;74:171-89.

6. Kassirer JP. Doctor discontent. N Engl J Med. 1998;339:1543-5.

7. Donelan K, Blendon RJ, Lundberg GD, et al. The new medical marketplace: physicians' views. Health Aff (Millwood). 1997;16: 139-48.

8. Hadley J, Mitchell JM. Effects of HMO market penetration on physicians' work effort and satisfaction. Health Aff (Millwood). 1997;16:99-111.

9. Hadley J, Mitchell JM, Sulmasy DP, Bloche MG. Perceived financial incentives, HMO market penetration, and physicians' practice styles and satisfaction. Health Serv Res. 1999;34(1 Pt 2):307-21.

10. Kerr EA, Hays RD, Mittman BS, Siu AL, Leake B, Brook RH. Primary care physicians' satisfaction with quality of care in California capitated medical groups. JAMA. 1997;278:308-12.

11. Mawardi BH. Satisfactions, dissatisfactions, and causes of stress in medical practice. JAMA. 1979;241:1483-6.

12. Murray A, Montgomery JE, Chang H, Rogers WH, Inui T, Safran DG. Doctor discontent: a comparison of physician satisfaction in different delivery system settings, 1986 and 1997. J Gen Intern Med. 2001;16:451-9.

13. Kravitz RL, Linn LS, Shapiro MF. Physician satisfaction under the Ontario Health Insurance Plan. Medical Care. 1990;28:502-12.

14. Linzer M, Konrad TR, Douglas J, et al. Managed care, time pressure, and physician job satisfaction: results from the physician worklife study. J Gen Intern Med. 2000;15:441-50.

15. Konrad TR, Williams ES, Linzer M, et al. Measuring physician job satisfaction in a changing workplace and a challenging environment. SGIM Career Satisfaction Study Group. Society of General Internal Medicine. Med Care. 1999;37:1174-82.

16. Haas JS, Cleary PD, Puopolo AL, Burstin HR, Cook EF, Brennan TA. Differences in the professional satisfaction of general internists in academically affiliated practices in the greater-Boston area. $\mathrm{J}$ Gen Intern Med. 1998;13:127-30.
17. Linn LS, Brook RH, Clark VA, Davies AR, Fink A, Kosecoff J. Physician and patient satisfaction as factors related to the organization of internal medicine group practices. Med Care. 1985;23:1171-8.

18. DiMatteo MR, Sherbourne CD, Hays RD, et al. Physicians' characteristics influence patients' adherence to medical treatment: results from the Medical Outcomes Study. Health Psychol. 1993; 12:93-102.

19. Haas JS, Cook EF, Puopolo AL, Burstin HR, Cleary PD, Brennan TA. Is the professional satisfaction of general internists associated with patient satisfaction? J Gen Intern Med. 2000;15:122-8.

20. Kaplan SH, Greenfield S, Gandek B, Rogers WH, Ware JE Jr. Characteristics of physicians with participatory decision-making styles. Ann Intern Med. 1996;124:497-504.

21. Burda D. Many docs mull early retirement-survey. Mod Healthc. 1994;24:38.

22. Aasland OG, Olff M, Falkum E, Schweder T, Ursin H. Health complaints and job stress in Norwegian physicians: the use of an overlapping questionnaire design. Soc Sci Med. 1997;45:1615-29.

23. Pincus CR. Have doctors lost their work ethic? Med Econ. 1995;72: 24-30.

24. Lewis CE, Prout DM, Chalmers EP, Leake B. How satisfying is the practice of internal medicine? A national survey. Ann Intern Med. 1991;114:1-5.

25. McMurray JE, Linzer M, Konrad TR, Douglas J, Shugerman R, Nelson K. The work lives of women physicians: results from the Physician Work Life Study. The SGIM Career Satisfaction Study Group. J Gen Intern Med. 2000;15:372-80.

26. Schwartz MD, Pathman DE, Bigby JA. Inner city physician job satisfaction: National Physician Worklife Study. J Gen Intern Med. 1999;14(suppl): 120.

27. Nadler ES, Sims S, Tyrance PH Jr, Fairchild DG, Brennan TA, Bates DW. Does a year make a difference? Changes in physician satisfaction and perception in an increasingly capitated environment. Am J Med. 1999;107:38-44.

28. Simon SR, Pan RJ, Sullivan AM, et al. Views of managed care-a survey of students, residents, faculty, and deans at medical schools in the United States. N Engl J Med. 1999;340:928-36.

29. Waterman $\mathrm{AD}$, Banet G, Milligan $\mathrm{PE}$, et al. Patient and physician satisfaction with a telephone-based anticoagulation service. $J$ Gen Intern Med. 2001;16:460-3.

30. Bodenheimer T. Disease management-promises and pitfalls. $\mathrm{N}$ Engl J Med. 1999;340:1202-5.

31. Kerr EA, Mittman BS, Hays RD, Zemencuk JK, Pitts J, Brook RH. Associations between primary care physician satisfaction and selfreported aspects of utilization management. Health Serv Res. 2000;35(1 Pt 2):333-49.

32. Novack DH, Suchman AL, Clark W, Epstein RM, Najberg E, Kaplan C. Calibrating the physician. Personal awareness and effective patient care. Working Group on Promoting Physician Personal Awareness, American Academy on Physician and Patient. JAMA. 1997;278:502-9.

33. Mechanic D. Managed care and the imperative for a new professional ethic. Health Aff (Millwood). 2000;19:100-11. 